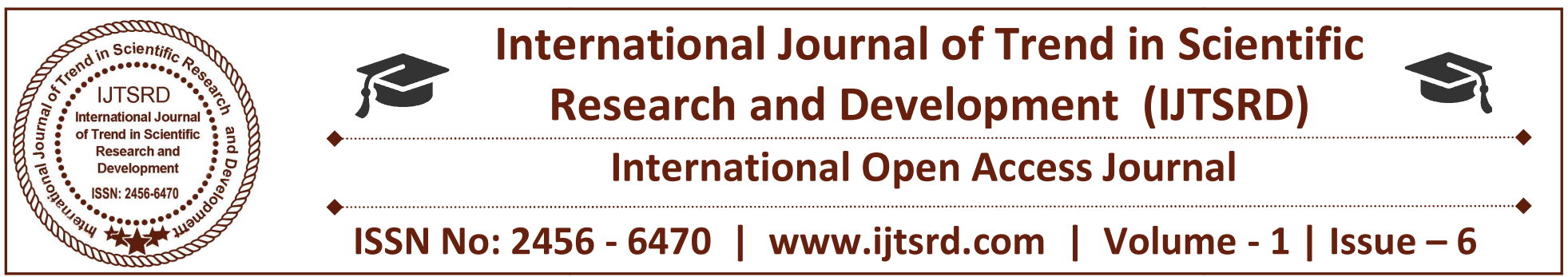

\title{
Intra-Elite Conflict and Problems of Governance in Nigeria: Imperatives of Games Theory in African Politics
}

\author{
I. S Ladan-Baki \\ Department of Political Science and International \\ Relations, Nile University of Nigeria, Abuja, Nigeria
}

\author{
C. Enwere \\ Department of Political Science and International \\ Relations, Nile University of Nigeria, Abuja, Nigeria
}

\section{ABSTRACT}

In modern African politics, terrorism and failed state syndrome have became prevalent and a challenge to democratic values and virtues of good governance, posing great threat and stress to the survival of domestic political systems. This increasing political stress is a product of competition and struggle for power and supremacy among players in the executive and legislative organs of government, which has reduced the parliament to a rubber stamp of power seekers as well as the use of electoral violence as instruments of regime change. Therefore, this study seeks to examine the root cause of political struggle and problems of good governance in Africa by analyzing the variables of intra-elite crisis in the parliament and the quest for establishment of spheres of influence by players in the executive arm. The rivalry between both elites has created tremendous problems of governance and the desires of incumbent presidents to elongate their tenure by using the legislature to amend the constitution to suit their third term bid as was seen in Burundi. The games theory is used as a tool of analysis to describe the roles of elites in the intra-power struggle for the control of the parliament which has made modern legislatures in Africa a new theater for proxy wars of domestic power seekers resulting in the collapse of parliamentary values and the ascendency of executive authoritarianism. This has made legislature in Africa weak and unstable culminating in the democratization of disempowerment of the citizens from the benefits of good governance, promoting poverty, political exclusion, apathy and frustration. Therefore, we conclude that intra-elite struggle for power has provided the political mechanism for reshaping and influencing the legislative processes and powers of the parliament to satisfy the self interest of power seekers.

Keywords: Intra-elite Conflict, Legislature, Executive, Crisis of governance

\section{INTRODUCTION}

The political behavior of Nigerian elites draws its core values from the legacies of the colonial state whose political culture was embedded in traditions of political totalitarianism. At the time of independence, Nigerian elites were less interested in the development values of modern democracy but more focused on promoting the paraphernalia of liberal democracy such as written constitution, independence of the legislature, multi-parties, separation of power and rule of law (Sorenson 1993:50-64). This misapplication of democratic values stimulated conflict of interests and struggle for power, prestige and supremacy among Nigerian parliamentary elites.

The parliament, therefore, became a theater of conflict for proxy interests of power seekers which culminated in the collapse of parliamentary democracy as seen in the 1962 crisis in Western Nigeria. The crisis was tacitly ignited by multi-sum struggle for power and prestige between the party leaders and the parliament as was seen at the 1961 conference of Action Group. This conflict of interests widened to unprecedented proportion resulting in hot fighting within the legislative chambers and many legislators were 
injured and the mace which is the symbol of parliamentary authority was broken. The ascendency of violent conflict over parliamentary values prompted the prime minister to sought parliamentary approval to declare a state of emergency in the federation, which eventually led to the collapse of parliamentary democracy and its replacement with military dictatorship. This crisis formed the structural foundation upon which the politics of parliamentary values, behavior and practice was built.

However, the second phase of parliamentary politics was kick-started by the demise of the Cold War in 1989 and this served as a turning point for power seekers in the parliament. The collapse of single party regimes throughout Eastern Europe and the former Soviet Union influenced Nigerian pro-democracy activists and sparked a new wave of democratic transition and legislative transformation in Nigeria.The authoritarian military leaders could no longer court the superpowers in exchange for protectionagainst political opposition. The containment policy has ceased to exist and a new Russian regime was preoccupied with domestic economic restructuring while the United States downplayed anti-communist political-military relationships in favor of promoting trade, economic investment and multi-party democracy (Peter, 2004:810). The reintroduction of multi-party politics encouraged the emergence of new competition for the control of legislative sub-structure of Nigerian politics.

Therefore, the post Cold War democratization process in Nigeria was covertly driven by intra elite competition for control over legislative machinery. The competition process was fraught with incompatible interests that have turned out to make the legislature weak and unstable. The competing nature of elite struggle for power is what Claude Ake described as the 'democratization of disempowerment' : a process whereby multiparty parliamentary elections in Nigeria allow for the rotation of self-interested political elites of different parties, while the majority of the population remains disempowered from the legislative processes and benefits. This process tends to represent the interests of political elites in their struggle for power as revealed in the inauguration of the National Assembly on June 9, 2015, which constitute the primary scope of this paper.
The inauguration of the $8^{\text {th }}$ National Assembly was characterized by intra elite conflict and struggle for power. This was as a result of the inability of the ruling All Progressive Congress party (APC) to adopt the zoning option, where strategic leadership positions were allocated to all the geopolitical zones to reduce the negative strife or quest for hegemony. But rather the party leadership resorted to hand-picking of legislative officers, which turned the National Assembly into a battlefield for proxy wars between the Yoruba elites and the Hausa/Funali elites for the control of the power structure of the parliament. Such covert conflict between the two ethnic power blocs provided the framework for the emergence of new players in the elite power game. The players are the Unity Forum Group, Like Mind Group, Peoples Democratic Party and the All Progressive Congress party.

The intensity of the struggle for power among the players eventually led to possible coalition among the players primarily to shape the outcomes of power struggle to their advantage. The 'Like Minds' group headed by Senator Bukola Saraki formed a political coalition with PDP ( the opposition party) while the 'Unity Forum' supporters of Senator Lawan Akume draws its support from the ruling APC party. Such reconfiguration of power posture brought about intense conflict among the APC political elites.

Therefore, in analyzing the dynamics of power politics and patterns of structural conflict in developing coutries especially in the Nigeria Senate, we will adopt a descriptive approach and contentanalysis of primary and secondary data extracted from documents accessed during a research fieldwork in Abuja, Nigeria. The sources include books, journal articles, monographs, occasional papers, bulletin, magazines, newspaper, newsletters and yearbooks. It is against this background that the paper will focus on the power struggle among Nigeria political elites using the games theory as a tool of analysis.

\section{Evolution of Nigeria Parliament and Intra Elite Conflict}

The modern day Nigeria has been the site of numerous empires, kingdoms and nation-states for millennia. Nigeria's legislative development history can be divided into four epochs: the pre-colonial, the colonial, post independence and post Cold Warepochs. The pre-colonial legislature was a creation of customs and culture, the colonial 
legislature was enacted through an order-in-council of the British monarch while the post-independent and post Cold War legislatures are products of an Act of Parliament and of a military decree respectively.

Contrary to Western conception that democracy and legislative institutions in Africa is a creation or an extension of European political culture and values, available historical evidence shows that legislature and separation of power was an integral part of African political system and values. The Oyo Empire that existed in present day Nigeria operated a political system that had all the essential attributes of separation of power and legislative culture (Peter 2004:30-31). The legislative organ of government in Oyo Empire was known as the Royal Council (Oyo Mesi) which enjoyed numerous formal political powers: the selection of the Alafin's successo (king) from a list provided by the royal clan in case of death or incapacitation; control over the process for choosing the Bashorun (the supreme military leader) and most important, the power to impeach the Alafin should he violate the norms and customs of the empire.

The existence of balance of power between the executive and the legislature in the Oyo Empire limited the unalloyed drive for power sruggle. The legislature serves as an important source of countervailing power similar to the United States model of checks and balances between the executive and legislative branch of government. Such institutional culture prevented intra elite conflict to dorminate legislative process and procedures in precolonial Nigeria.

Therefore, the modern day intra elite conflict and parliamentary crisis has its root in the Bristish colonial rule in Nigeria whose motive was aimed at the democratization of alienation which enssured the alienation of Nigerian elites from the legislative process while promoting the domination of British elites. Such politics of interest marked the history of parliamentary development in Nigeria during the colonial era. The history of Nigeria parliament began in 1914 with the Frederick Lugard Constitution.

The constitution not only led to the amalgamation of the protectorate of Souther Nigeria with the Protectorate of Northern Nigeria but also created a Legislative Council of the colony. The Council was restricted to making laws for the colony of Lagos alone, whilst the Governor General made laws for the rest of the country. Because of the incompataibility of interests between the British colonial elites and the emerging Nigerian elites, brought about structural agitations that led to the collapse of the legislature.

However, the 1914 legislature was replaced in 1922 with a new legislative council based on elective principle by the introduction of Clifford Constitution. The constitution established a 46 member Legislative Coucil that was given law making responsibilities for the Lagos Colony and the southern provinces. The elective principle enabled Lagos and Calabar to elect their representatives to the legislative council. Again, the Clifford legislature was limited by the ascedency of conflict of interests, aspirations and goals between the British and Nigerian elites over who dictates the power flow of the legislature.

In 1946, Arthur Richard tried to restructure the composition and powers of the legislature with the introduction of a new constitution. Influenced by the new waves of nationalism in Africa after the second World War, Nigerian political elites began to organize themselves into political associations that culminated in the formation of the National Council for Nigeria and Cameroons. The essence was to mobilize the indigenous elites to introduce the virtues of selfdetermination and the quest for political independence in the legislative organ. The 1946 legislature provided the framework for the introduction of unofficial majority both in House of Assembly and the legislative council for indigenous Nigerian elites.

Similarly, the Macpherson legislature of 1951 brought about a major advancement on the old legislative order by introducing Nigerian elected majorities in the central legislature and in the regional legislature endowed with independent legislative power in many areas of state activity. The collapse of 1946 and 1951legislatures was the inability of the colonial political elites to manage inherent tensions and conflicts caused by lack of insightful national leadership for the management of incompatiable interests which resulted in the eruption of violent conflicts between the southerners and northerners in Kano as well as massive loss of lives and property.

Consequently, the 1954 legislature established by Lyttleton Constitution gave autonomy to regional legialatures in the areas of residual powers. This was made possible by the introduction of unicameral legislature for the federal government and each of the three regional governments. The Lyttleton 
Constitution provided the transitional mechanism for the independence of the legislature with a democratically elected membership. Dsepite these democratic innovations, the colonial legistrature destroyed the structural values of separation power between the excutive and legislature inherent in precolonial Nigerian political system and replaced it with a legislature characterized by incompataible interests and intra elite conflict. Such structural conflict became the pillars on which the post independent Nigerian parliament was built.

The structural changes of the constitutional conferences of 1950s cumulated in the granting of Nigeria the status of political independence as a sovereign state and the establishement of a new legislature based on Westminister model of parliamentary democracy, which recognized the British monarch as the Head of State with powers to appoint a resdent agent (Governor-General) to exercise executive powers on her behalf while the Prime Minister elected by the federal parliament acted as the Head of the federal executive council. In addition, the constitution provided for a bicameral legislative framework at the federal (Senate and House of Representatives) and at the regional levels, the House of Assembly and the House of Chiefs with the legislative powers delineated into three categories or lists: exclusive, concurrent and residual lists.

Howeverever, despite these legislative innovations, the parliament was characterized by structural conflicts and tacit power struggle between the Nigeria political elites and the British power seekers. The Nigerian elites argued that the Governor-General should be a representative of the people rather than an agent of the the British Queen; since such structural arrangement had made Nigeria a dominion territory, which contradicted the very nature and principles of parliamentary sovereignty. Such functional arrangement denied Nigeria elites an effective independence in the exercise of legislative powers. This led to crisis in delineation of the functional roles of post independence parliament. Such fundamental derogation and other observed functional crisis in the running of 1960 parliament led to the enactment of the 1963 Constitution and the reformation of parliamentary procedures and values.

The 1963 parliamentary reforms addressed the structural dependence of Nigeria legislative elites on the imperal elites and dictations. Though the 1963 parliament retained the British model of parliamentary
democracy.But the reforms insured that the GovernorGeneral was elected directly by members of the federal legislature and not appointed by British monarch.

Thus, the holistic exercise of legislative powers by Nigerian elites created new horizons for inter elite power struggle between the legislature and the executive and intra legislative conflicts between the ruling party and the opposition which resulted into crisis and tensions in the political system as well as the declaration of state of emergency in some parts of Nigeria. Hence Nigeria became a theatre of intra elite crisis and the resultant chaos prompted the military to set aside the parliament by a violent coupd'etat. The coup led to a counter coup headed by Gowon and the masarcre of the Igbo people by the Northerners. These events encouraged the secession of Biafra, the civil war and the collapse of the political system.

Therefore, the intra elite crisis in the 1963 parliament created multiplier effects of violence and stress in the political system that introduced military coup and violence as an instrument of political change. This vice of political violence was assimilated into the political culture of Nigeria as a rational method of regime change. As were seen in 1976, 1983, 1985 and 1993 military coups and change of governments by General Mutala Mohammed, Muhammed Buhari, Ibrahim Babagida and Sani Abacha respectively. Hence, the military regimes discarded the legislature because of its perceived observation that the existence of the parliament provides the catalyst for violent conflicts and intra elite fightings.

Therefore, the reintroduction of parliamentary politics by the military became a tool for political experiments to test its validity and relevance. This prompted General Olusegun Obasanjo military regime to establish the 1979 legislature through the enactment of 1979 Constitution. The Constitution abandoned the Westminister model and opted for the American presidential system of government and called the parliament, the National Assembly and not Congress. It provided for yet another bicameral legislature comprising of 450 member House of Representatives and a 95 member Senate both jointly referred as the National Assembly. Again the parliament became a centre of elite power struggle and confrontation between the opposition and the ruling party. Thus, the legislature once again became the first target of military adventurists, as it was dissolved by General Muhammed Buhari military regime, based on the 
premise that the existence of the parliament will provide the mechanism for power struggle between the legislative elites and the military elites which may bring about policy crisis and supremacy race.

Hence, the parliament once again became a specimen for political experimentation. In 1989, General Ibrahim Babagida experimented possibility of mixing parliamentary politics with military administration by creating yet another bicameral legislature. But the fusion of parliamentary democracy with military totalitarianism led to the polarization of the legislature and the ascedency of conflict of interests over parliamentary values. Thus, the parliament was badly polarized after the annulment of June 12 presidential election, between those in support of General Babagida's self-succession agenda and those against it. These serial vicous circle of parliamentary crisis and the collapse of military-parliamentary fusion created the political events that made General Abacha to dissolve the parliament. Nigeria was again deprived of a parliament for six years from 1993 to 1999. Hence, the prolonged presence of the military in Nigerian politics created a mechanism for executive supremacy and a culture of legislative peripheralisation and subordination to the executive organ of government (Adewale, 2013:135-144)

But the Cold War's end in 1989 served as a fourth turning point in the history of parliamentary politics in Nigeria. The collapse of single-party regimes throught Eastern Europe and the former Soviet Union powerfully influenced Nigerian pro-democracy activists and sparked a new wave of democratic transistions that led to the reestablishment of the legislature in 1999. The 1999 Constitution again provides for a bicameral legislature. Chapter 5 of the 1999 Constitution stipulates that the federal legislature should be made up of two houses: the House of Representatives with 360 members and the Senate comprising of 109 members.

Yet the greatest challenged that faced the 1999 parliament was the onerous task of redefining its status and assertiveness from executive dormination and subordination. This created inter elite conflict between the executive and the legislature that resulted in parliamentary instability and contant removal of Senate presidents. But in 2015 with the emergency of $\mathrm{APC}$ as the ruling party, the legislature was again confronted with yet another obstacle that threatens its independence. Thus the legislature is involved in intense struggle with the party elites over the appointment of key officials in the parliament. Just like the executive under PDP from 1999-2014, the APC party elites tacitly desire to subordinate the legislature to party controi and supremacy, hence the beginning of another elite crisis in the National Assembly.

\section{Parliamentary Crisis Under Peoples Democratic Party (PDP) from 1999-2014}

The parliamentary crisis under PDP was a game of strategy between the political elites in the executive and emerging elites in the legislature over the politics of legislative independence and executive supremacy. The executive headed by a former army general from 1999-2007 in his quest to consolidate the military perception of legislative subordination and exclusion as an appendix of the executive, created large scale intra-senate conflict that cannot be compared to any in the history of Nigerian parliament. The struggle over the independence of the legislature that started during the the colonial era through the long years of military rule became so intense and confrontational under PDP administration. The executive see the legislature as a pawn in the game of politics that shall be used according to the whims and caprices of the political elites in the executive arm.

In order to subordinate the legislature to executive control and manipulation, the politics of impeachment was covertly introduced which created more conflicts than collaboration in the National Assembly. Jide Ajani ( Vanguard 29 May, 2003) observed that impeachment or removal from office of Senate presidents was one aspect of 1999 Constitution that was given accommodation by the political elites with unbridled rascality. The reasons for impeachment ranged from nepotism, autocracy, embezzlement of public funds, lack of probity and favouritism. These reasons provided the guise to stimulate conflicts to make the legislature subservient to executive hegemony. Therefore, the crisis of impeachmen and forced resignations of Senate Presidents between 1999 and 2007 will be categorized under the following epochs:

\section{June-Novermber 1999 Epoch}

This period was characterized by power struggle between the legislature and the executive as well as intra-legislative conflict among power seekers. This was demonstrated in the emergence of Evan Enwerem as the Senate President, when the political elites in the executive mobilized senators from the opposition 
party particularly All Nigeria Peoples Party (ANPP) and Alliance for Democracy (AD)to defeat some PDP elites that were out to truncate the executive's will of Enwerem's candidacy. This led to executivelegislative rivalry and Enwerem's inclination to tacitly promote legislative independence, which was interpreted by the executive as uncharismatic, lackluster and without direction. To the executive it was time to invoke the constitutional provisions of Article 1, section 2 and 3 of the 1999 Constitution as a legitimate instrument of state policy to impeach the Senate president and and denigrate its quest for supremacy.

To achieve this aim, the executive went into alliance with conflict players in both House of Representatives and Senate to achieve a pre-determined outcome of subordination of National Assembly in the power game (Nkem, 2001: 11). For this reason, the House of Representatives commenced a boycott of all joint sessions insisting not to return until the Senate president was removed. On the other hand, the conflict entrepreneurs in the Senate moved a motion for the impeachment of the Senate president on three grounds (Felix, 1999:2):

I. That the executive arm of government has developed undemocratic and dictatorial tendencies due to the subversion of the legislature which is not independent, lacks confidence, drive and enterprise.

II. That the progress and existence of the country's nascent democratic dispensation is endangered by events which eroded the moral authority of the senate.

III. That there is need to determine the position of the senate president because the senate lacks the moral authority and capacity to stand up to the executive arm of government, defend and promote the interest of the legislature in Nigeria.

Based on the above reasons, a vote of no confidence was passed on the senate president and on Novermber 18, 1999 he was removed through an overwhelming vote of 92 to 2 . His tenure only lasted for six months. During this era, nothing meaningful was achieved but rather the legislature was embedded in crisis while the executive strives in its hegemonic influence and control of the parliament.

\section{Novermber 1999- August 2000 Epoch}

With demise of Enwerem as the senate president, Chuba Okadigbo was elected president and his tenure witnessed a revivalism of legislative independence and an attempt to contain executive dormination of parliamentary activities. He cultured the values of parliamentary dignity, intergrity and the requisite capacity needed for securing separation of power between the parliament and the executive. Under Okadigbo's leadership, more than forty bills were presented to the Senate within the space of nine months (Celestine, 2002:9).

Despite these achievements, intra PDP elite rivalry dominated senateproceedings and the senate was caught up into two conflicting worlds: the sustenance of legislative independence and the perceived alienation PDP elites by the charismatic hegemony of Senate president style of leadership. Thus, the executive arm of government exploited the division among key players in the senate to tacitly undermine parliamentary politics of supremacy to its advantage by creating more conflict players. The entrance of conflict entrepreneurs into the strategic power game between the executive and the legislature led to the creation of more power blocs in the senate which facilitated proliferation of incompatible interests, positions, fears and needs. This followed allegations of public disdain arising from the inability of the senate to pass the 2000 Appropriation Bill, leadership arrogance, contract scam and financial wrongdoings.

However, in his desperation to prove his innocence, integrity and containment of executive influence a panel was ste up headed by Idris Kuta to investigate the allegations. On the basis of the investigation, the panel indicted the senate president and recommended for his removal from office. On August 10, 2000, the senate adopted the recommendations of the panel under intense pressure and lobbing from the executive elites and consequently the senate president was impeached.

During this period, the senate president and his alliesspent more time staving off attempts of impeachment than on legislative duties and operations. Hence, the legislature under this era suffered another major setback from attaining the much desired operational independence that would have given it a great voice in the development of democratic values in Nigeria. So, the legislature 
submerged deeper into executive manipulation, subordination, alienation and disempowerment.

\section{Anyim Pius Anyim Era.}

With the removal of Okadigbo, Senator Anyim emerged as a consensus candidate between the Senate and the Executive, indicating the influence of the executive in shaping political events in Nigerian parliament ( Makinde, 2001:10-15). Despite this tacit agreement between the exexcutive and the senate, yet the senate was highly polarized and weighed down by factions and personality cult struggle reflecting the traditional outcome of executive-legislature supremacy rivalry. Anyim understood the inherent variables of this inter-elite conflict, since he was one of the key conflict actors in this game of prestige.

For this reason, Anyim moved with caution and tried to toe the middle course of carring both the legislative actors and executive actors along so as to create a new framework of interactive collaboration that will ensure the smooth operations of tenets of separation of powers (Mthisen, 2001:50). To achieve this covert objective, the senate president procured political favours from the executive in order to balance power, interests and fears. This was reflected in the Electoral Act Constitutional reforms of 2001, in which he tried not only to allow the wishes of the parliament to prevail but also accommodate the interests of the executive.

Thus, such tacit collaboration with the executive political elites ired some of political elites in the legislature that arosed feelings of apathy among senators particularly in attending plenary sessions. The senate hardly form a quorum and the few senators who arrived in the chamber would wait for hours before a quorum of 35 senators is formed.This politics of alienation created the cataclysmic forces for the reemgergence of executive-legislative conflict.

However, the most defining variable of the new interelite conflict was the attempt to impeach President Olusegun Obasanjo, one of the key actor in the legislative-executive game of strategy. The House passed a motion on the State of the Nation and gave the President a two-week ultimatum to either resign from office or face impeachment proceedings. The President was accused of non-implementation of 2001 Appropriation Act as passed by the senate. The impeachment option was the first time the parliament confronted the political elites in the executive in the history of executive-legislative power game.
The executive felt threatened and adopted its own strategy of survival. This involves the 'legislaturization of the conflict' by recruiting conflict entrepreneurs in the legislature headed by Arthur Nzeribe to create conflicts of interests in the legislature using monetary lobbing, accusations of financial scam and impeachment threats as weapons of mass destruction of the power capability of the parliament. Nzeribe kicked off a controversy alleging that N300 million had been shared among senators to get them drop the impeachment proceedings against the president. He claimed that he coordinated the sharing of the money and alleged that the senate president collected N60 million. This strategy of financial scam was used by conflict players in the past to secure the impeachment of senate presidents and it had now become one of the survival strategies of the executive to undermine the independence of the parliament.

Therefore, both the legislature and the executive became intergled in the new waves of hegemonic conflicts over who will control the political order and rules of the power game in Nigeria. This is what Ken Booth (2007) described as 'Survival Plus' which permits the ability of actors to pursue cherished political and social interests free from threats and predetermined choices. In the pursuit of the survival plus, the senate adopted a new strategy to contain the influence of the executive in using senators as tools for creating latent threats to destabilize the parliament. In implementing the strategy, the senate identified the allies of the executive in the senate and suspended its key player, Arthur Nzeribe on the basis of finanacial misappropriation. His suspension rattled down the hegemonic influence of the executive and provided the basis for negative peace, through which the senate president completed his tenure without quick incursions into legislative activities by political elites of the executive arm of government.

\section{Contemporary Parliamentary Crisis Under All Progressive Congress (APC).}

Historically, in 2013, the four strongest opposition parties namely: ACN, CPC, ANPP and a faction of APGA come together to form APC in order to systematically build a formidable party to contest the 2015 election. The new party described itself as a leftist-progressive party and has diverse geographical spread, covering five out of six geopolitical zones. So, APC's zones of influence included North East, North Central, North West, South West and some parts of 
South East. This reflected its geopolitical power before the 2015 presidential election.

This geopolitical influence played out itself in 2015 election where it got $25 \%$ of total votes cast in twothird of 36 states and with a majority seat in the Senate with 62 seats out of 109; in the lower House of Representatives, it has 225 out of 360 seats while at state level it secured 20 states out of 36 states in Nigeria. This shows that APC spheres of electoral influence cuts across the major political divides of the country.

The APC coalition created a very strong political bloc with a common political agenda for the purpose of contesting and wining the presidential election. Nigeria political history is replete with failed political party alliances and mergers but APC's successful merger is the first time that strong political parties in Nigeria are shedding their identity and merging into one party strong enough to win a presidential election.

Despite these electoral victories at the executive and legislative levels, the greatest challenge lies in the constitution of the parliament. In his inaugural address, the president, Muhhamed Buhari affirmed that the executive would not interfere in internal politics of the parliament. This confirms the maturity of the president and demonstrates the spirirt of democracy and separation of power. The president's posture and indifference to politics of executivelegislative confrontation created a vaccum among power seekers. Since there is no vaccum in power game, new power seekers and players emerged from within the ruling party to play the politics of hegemony over the parliament in order to determine who gets what, when and how.

\section{New Players in Executive-Legislature Power Game for Strategic Hegemony.}

Since the politics of every political system is determined by the interests and fears of power seekers, the perceived indifference of the political elites in the executive arm resulted in a ctatclysmic rise of new power seekers willing to overtake the executive to dominate the legislature and policy direction of the country. These power seekers drew their driving force from Section 50 of the Constitution which explicitly explains the process of electing the leaders of the National Assembly. It states that the exercise must be carried out inside the two chambers among the members without outside interference. Therefore, it is generally belived by Nigerian political elites that whosoever controls the internal election of principal officers of the legislature, controls the parliament and what it does. In this direction, the following conflict players emerged to determine the outcome of June 9, election and inuguartion of the leadership of the $8^{\text {th }}$ National Assemply.

\section{APC Political Party.}

The decision makers in APC are mainly from the southwest dominated by the Yoruba ethnic group with Ahmed Tinubu as their leader.The party chairman and secretary are members of his political association. Having controlled the party structures and the the president's unwillingnesss to get involved in parliamentary politics, the Tinubu group using the party as a tool moved to control the parliament and its internal election process. The essence is to control the policy direction of the parliament and indirectly the agenda setting for the executive since the vice president, a Yoruba is a member of this new crop of power seekers.

The interests of power seekers in the ruling party is in sharp contrast with the policy goals of political elites in the executive whose primary aspiration is to accommodate the independence of the legislature and avoid or minimize the historical legislature-executive acrimony and power struggle. This conflict of interest between the executive and the party created two conflicting political ideas within the elites of the ruling party: the party in its assertion believes in the supremacy of the party over the parliament while the executive insists on separation of power. Hence new horizons of conflict came into being leading to power race over the control of the legislature.

\section{PDP Political Party.}

Having lost the 2015 elections and it political hegemony after 16 years in power, the Peoples Democratic Party (PDP) eventually became an opposition party and a power seeker in the race to control parliamentary politics. Using its numerical strength of 45 senators as against APC's 54 senators the PDP players moves to determine who controls the power mechanism of the parliament. Its interest is to remain relevant in parliamentary politics with the hope of winning majority seats in 2019 election. The PDP ultilizedthe crack within the ruling party elites to make itself a key actor in the game of hegemony in the legislature. 


\section{Unity Forum.}

The Unity Forum is a shadow power seeker within the parliament, that draws its political strength from the APC party elites and is headed by Senator Lawan and George Akume. Both Lawan and Akume were selected to contest the position of sentate president and deputy Senate president respectively. They were drawn from the political bloc of Northwest and Northeast geopolitical zone while Gbajabiamila was positioned to head the House of Representatives as Speaker, selected from the southwest geopolitical zone. The essence of this triparte alliance was to streghten the power capability of the group in the parliament which will be used as tacit instrument to influence the policy thrust and intent of the executive organ of government. This group draws its political strength from the shadow political elites of the southwest geopolitical zone, so as to prevent the northern elites from controlling the executive power as well as the legislative power.

\section{Like Mind.}

The Like Mind political lobby group is also a shadow power seeker in the parliament that draws its political strength from the North and seeking to dorminate the politics of the parliament. This group is headed by Senator Bukola Saraki. In its strategic quest for power, the group covertly entered into an alliance with the opposition party (PDP), whose memebership were former PDP political gladiators, that defected to APC primarily to win election.In order to consolidate its power relation with the PDP, the group zoned the position of Deputy Senate president to PDP, Senate president to Northcentral while the position of the speaker of House of Representatives was zoned to Northcentral. The interest of this group is to create a triangular power bloc between Northcentral and PDP's power zones of Southsouth and Southeast geopolitical zones so as to control the power politics of the parliament and shape the interests of the opposition, which will be used as a proxy to influence executive policies.

However, the above identified players in the power game of Nigerian parliament, can be classified into two major categories: Primary Player and Shadow Player. The primary player are visible players in the power game who are commonly known and this consists the Like Mind Group and the Unity Forum. On the other hand, the shadow players are indirect or invisible players who are not commonly known and this include the opposition party (PDP) and the ruling party (APC). Their involvement in the power game in 2015 parliament is indirect and by proxy. These shadows stimulate conflict into the game process, thereby complicating the outcome of the power game, because it is difficult to identify their roles. So, in their quest to expand their spheres of influence and hegemonic control of the parliament, both the shadow and primary players became engrossed in power reconfiguration and alliance formation (Zagare and Kilgour, 2000). To this end, the 'Like Mind' considered a coalition with the opposition party while the 'Unity Forum' maintained its traditional alliance with the ruling party.

\section{Outcomes: Central Tenets and Mixed Motives.}

The decisions that players make eventually lead to an outcome (Nasar, 1998). In the parliamentary power game in Nigeria, the empirical content associated with its outcome vary as the intensity of the game increases. The outcome come either in form of conflict or comprise created through the interactive decision making strategies of the players as follows:

\section{Intra Party Mock Primary Election.}

The introduction of mock primaries into the power struggle between Unity Forum and Like Mind group was intiated by the shadow player (APC) in order to influence the outcome of intra parliamentary election for the selection of senate president and speaker of the House of Representatives. The player that occupies the position of senate president and speaker will not only become the guiding force behind the development of legislation but will also determines who gets what, how and when in the allocation of parliamentary resources and values. Aside, the senate president and speaker have the power to set the political agenda for the country and also have the power of recognition to determine which legislator will speak from the floor.

In their quest to control the parliament, the Unity Forum and its ally the ruling party designed the structure of the mock election and adopted it as the party's position based on the assertion that the party is supreme and its interest is superior to that of individual members. This assertion stems from the inability of the ruling party (APC) to settle on a single candidate in its caucuses in the Senate and the House of Representatives (Editorial, 2015:19). Hence, the mock election was designed as conflict tool to intimidate the Like Mind group, so as to shape the 
outcome of the power struggle in favour of the ruling party elites, through the use of open ballot system.

So, through the instrumentality of open ballot system the shadow actors in the APC ruling party hope to use it as a strategy to prevent supporters of the Like Mind group from voting for fear of repraisal sanctions from the party governing elites. Hence, the leadership of the party settled for Femi Gbajabiamila and Mohammed Monguno as the party's sole candidates for the mock election for the speaker and deputy speaker of House of Representatives. To this effect, 182 out of 209 APC lawmakers was present at the mock election. During the voting process, 154 members voted for Gbajabiamila of Unity Forum while only 4 members voted for Dogara of Like Mind Group (Nwosu, 2015:6). But 24 members refrain from voting by working out of the voting centre while 27 members did not attain the mock election. Thus, the outcome of the mock election was a zero-sum outcome in the the interests of the Unity Forum and Like Mind Group are diametrically opposed. The outcome favours the Unity Forum while the interest of the Like Mind Group was circumvented. Hence, a strategy of walk-out was used by the Like Mind bloc as a tool to manuevre the outcome so as to gain comparative advantage in the game process. Therefore, they argue that the open ballot system was a negation of the party's constitution.

However, the insistence on the use of open ballot by the party was interpreted by the Saraki's Like Mind group as a strategy to coerce the senators-elect to toe the line in elecfting the party's preffered actors. Therefore, the Like Mind actorsopted out of mock election insisting on open secret ballot system in agreement with the party's constitution. Under the quise of promoting internal democratic principles in the party, the Saraki's political bloc rejected the result of the mock election and entered into strategic alliance with PDP senators on how to influence the substantive election of the senate to its comparative advantage. While the Unity Group insists that the mock election serve as a catalyst to synchronize the divergent interests of the APC senators elect to speak with one voice during the intra-senate election, to ensure the hegemony of party interests over individual motives. Such clash of perception and incompatibility of interest created a new form symmetric conflict in APC and the politicization of the mock election processes and results. Hence, the symmetric conflict turns into a battle of hegemony between the independence of the legislature and the party's internal democratic values.

\section{National Assembly Leadership Election.}

Under the quise of mock election and internal party democracy, the governing elities in the executive opted not to elect but to systematicaly select or appoint party loyalists as Senate President and speaker of the House of Representatives repectively, primarily as a tool to influence and redirect the law making thrust of the parliament to executive control and manipulation. Such strategic manipulation was resisted by the House of Representatives with the election of Aminu Tambuwal as speaker contrary to the dictates of the executive. It was a holistic ressistence by the National Assembly to assert its independence from the executive arm of government by holding on to the provisions of 1999 Constitution which states that 'the senate shall elect its principal officers from among themselves'. This informs the desirability of the 'Like Mind Group' to go for election and reject the result of the mock election.

Therefore, at the senate election, Saraki of APC-Like Mind Group won the presidential election by 57 votes and was pronounced elected as Senate President. Ike Ekweremadu of PDP and a proxy member of the Like Mind Group won 54 votes to Nduma of APC's Unity Forum 20 votes to be elected as Deputy Senate President. In the House of Representatives, Yakubu Dogara of Like Mind Group polled 182 votes to beat Femi Gbajabiamina of Unity Forum who secured 174 votes to become the Speaker of the lower House.For the position of Deputy Speaker, Suleiman Yusuf of Like-Mind Group defeated Mohammed Mongunu of Unity Forum by 203 votes to 153 votes ( Obafemi, 2015:9).

The outcome of this election shows the strategic victory of Like-Mind Group over Unity Forum. This tend to assert the independence of the parliament and the declining influence of executive control in internal parliamentary politics. This was re-echoed by the Senate President elect in his acceptance speech. He insisted that the mock election was a flagrant mockery of democracy and the intra parliamentary election reveals the victory of the independence of the legislature from both the executive arm of government and of the party.This implies that the victory of Tambuwal in the $7^{\text {th }}$ Assembly and the subsequent victories of Saraki and Dogara in the $8^{\text {th }}$ Assembly depicts the incremental struggle by 
legislators to assert their supremacy and independence as well as freedom from executive control.

\section{CONCLUSION}

Having given a detailed evaluation of parliamentary politics and the quest to institutionize the values and virtues of good governance in Africa, African political actors through their innate struggle for power insidiously undermine the true tenets of democratic governance as seen in Nigeria political process. The research reveals that the European powers through the mechanism of colonialism institutionalized intra-elite power struggle between the executive and the parliament, which has become a spectre that is hurting the embers of good governance in modern Nigeria state. This was demonstrated in Nigeria from 1999 to 2007, when the Nigerian parliament witnessed tremendious political stability as its leadership became a pawn in the hands of the executive, who changed them at will. The battle for supremacy between the elites in the executive and the legislature has divided the Nigeria political system along tribal and religious lines, thereby constituting a $\log$ in the wheels of democratic practice and values. Therefore, we conclude that the quest by the elites in the executive arm of government to influence and control parliamentary process and procedures is a function of political stability and underdevelopment in Africa.

\section{REFERENCES}

1) Makinde.B, M. (2001). Who's who in Nigeria. Newswatch.

2) Abugu, F. (2001). Anyim's Senate and Quest for Stable Democracy. The Vanguard.

3) Banjo, A. (2013). Leadership Crisis in the Parliament of Nigeria: The Case of the Senate in the Fourth Republic. Journal of African Studies and Development.

4) Ken, B. (2007). Theory of World Security. Cambridge: Cambridge University Press.

5) Mathisen.H.W. (2001). Does Parliament Matter in New Democracies. Bergen: CMI.

6) Ndibe, N. (2001). Restoring Intergrity to the Senate. The Gaurdian.

7) Okafor, C. (2002). The Senate Hammer. The Vanguard.
8) Schraeder, P. (2004). African Politics and Society. Wadsworth: Clark Baxter.

9) Williams, P. (2008). Security Studies: An Introduction. New York: Routledge. 